\title{
HARGA DIRI MANTAN PECANDU NARKOBA YANG BEKERJA DI PUSAT REHABILITASI " $X$ ” JAMBI
}

\section{THE SELF-ESTEEM OF EX-DRUG ADDICTS WORKING AT THE " $X$ " REHABILITATION CENTER IN JAMBI}

\author{
${ }^{1}$ Tira Nalvianti Rahmi, ${ }^{2}$ Siti Raudhoh, ${ }^{3}$ Amelia Dwi Fitri \\ ${ }^{1,2}$ Department of Psychology, Jambi University/tiranrahmi@gmail.com \\ ${ }^{3}$ Department of Medicine, Jambi University
}

\begin{abstract}
Introduction: Ex-drug addicts might potentially experience a relapse. Previous research had found that one of the factors that could affect ex-drug addicts to survive from a relapse was selfesteem. Self-esteem is essential for every human being, especially for the ones who are in their recovery, such as addiction recovery. This research aimed to describe the self-esteem of ex-drug addicts working at a rehabilitation center.
\end{abstract}

Method: The participants of this research were three men working at a rehabilitation center and had stopped using drugs minimum in a year. This research was conducted in Jambi in 2018, used a qualitative research method with a phenomenology approach. The data collection technique used an in-depth interview.

Result: All of the participants still disregarded some values yet had some appropriate experiences in other aspects of self-esteem. The main factors that significantly contributed to their self-esteem were relatively different.

Conclusions and recommendation: It appears that the self-esteem of all the participants tends to lead to the mediumcategory

Keywords: addiction recovery, ex-drug addict, rehabilitation, self-esteem

\begin{abstract}
ABSTRAK
Latar Belakang: Mantan pecandu narkoba yang berhasil lepas dari ketergantungan narkoba berpotensi untuk mengalami kekambuhan. Penelitian sebelumnya menemukan salah satu faktor yang dapat mempengaruhi mantan pecandu narkoba mampu bertahan untuk tidak kembali menggunakan narkoba adalah harga diri. Harga diri penting dalam kehidupan seseorang, terutama bagi seseorang yang sedang dalam masa pemulihan, seperti pemulihan adiksi. Penelitian ini mendeskripsikan mengenai harga diri pada mantan pecandu narkoba yang bekerja di pusat rehabilitasi "X" Jambi.
\end{abstract}

Metode: Partisipan penelitian ialah tiga orang laki-laki dewasa yang berusia antara 25-45 tahun, sedang bekerja sebagai staf di pusat rehabilitasi " $X$ " Jambi, dan telah berhenti menggunakan narkoba minimal satu tahun. Penelitian dilakukan di Kota Jambi pada tahun 2018, menggunakan metode penelitian kualitatif dengan pendekatan fenomenologi, serta metode pengumpulan data melalui teknik wawancara mendalam.

Hasil: Ketiga partisipan masih belum memenuhi beberapa nilai-nilai kebajikan, namun partisipan telah berhasil memenuhi sebagian besar nilai yang terkandung dalam aspek harga diri. Faktor yang paling berperan dalam pembentukan harga diri masing-masing partisipan secara khusus memiliki perbedaan yang mendasar. 
Kesimpulan dan Saran: Harga diri ketiga partisipan cenderung mengarah ke dalam kategori harga diri sedang berdasarkan keseluruhan aspek yang hampir terpenuhi dan beberapa yang tidak terpenuhi.

Kata kunci: harga diri, mantan pecandu narkoba, pemulihan adiksi, rehabilitasi

\section{Pendahuluan}

Narkoba adalah akronim dari narkotika, psikotropika dan bahan adiktif lainnya atau dapat pula menjadi narkotika dan bahan berbahaya lainnya. Sedangkan NAPZA adalah akronim dari narkotika, alkohol, psikotropika, dan zat adiktif lainnya. Gangguan penggunaan narkotika, psikotropika dan zat adiktif lain (NAPZA) merupakan masalah yang menjadi keprihatinan dunia internasional di samping masalah HIV/AIDS, kekerasan (violence), kemiskinan, pencemaran lingkungan, pemanasan global dan kelangkaan pangan. Situasi global penyalahgunaan narkoba di dunia cukup mencengangkan (Martini, dkk, 2015). Hampir seperempat miliar orang pada rentang usia 15-64 tahun diperkirakan menggunakan narkoba pada tahun 2013. Dengan data yang ada saat ini, dapat diketahui bahwa prevalensi umum telah mencapai angka 5,2\%, artinya angka estimasi penyalahgunaan narkoba sebenarnya mengalami peningkatan dari 6 juta jiwa menjadi 246 juta jiwa (BNN, 2015).

Indonesia merupakan negara kepulauan terbesar di dunia dan memiliki letak geografis yang unik dan strategis. Indonesia memiliki jumlah penduduk yang besar, dengan laju pertumbuhan penduduk Indonesia sebesar $1,49 \%$ per tahun serta rerata tingkat kepadatan penduduk Indonesia sebesar 124 orang per $\mathrm{km}^{2}$. Kondisi demikian merupakan pangsa pasar potensial bagi peredaran gelap narkoba (BNN, 2015). Berdasarkan data dari Kementerian Kesehatan RI (2014), jumlah kasus narkoba berdasarkan penggolongannya yang masuk dalam kategori narkotika terus mengalami peningkatan dalam 5 tahun terakhir, sedangkan yang masuk dalam kategori psikotropika jumlah kasusnya semakin menurun.

Sementara itu, di provinsi Jambi sendiri selama Januari hingga Juli 2016, pihak kepolisian Polda Jambi dan jajaran berhasil mengungkap sebanyak 536 kasus pidana narkotika dengan mengamankan sebanyak 870 tersangka dan barang bukti sabu 2,63 kilogram, ganja 5,32 kilogram dan ekstasi 11.972 butir. Pada tahun 2016, berdasarkan hasil data Badan Narkotika Nasional (dalam news.okezone.com, 2016), provinsi Jambi tercatat masuk dalam kategori empat besar nasional tingkat provinsi untuk peredaran narkoba di Indonesia.

Penyalahgunaan narkoba dan zat adiktif lainnya merupakan perilaku yang dapat berdampak pada kondisi kejiwaan yang bersangkutan, serta menimbulkan masalah lingkungan sosial. Masyarakat secara umum memandang masalah penggunaan narkoba lebih sebagai masalah moral disamping juga masalah kesehatan (Kemenkes, 2014). Saat seseorang menjadi seorang pecandu narkoba mereka akan dihadapkan pada pilihan untuk menjalani rehabilitasi. Rehabilitasi terhadap pecandu narkoba adalah suatu proses pengobatan untuk membebaskan pecandu dari ketergantungan, dan masa menjalani rehabilitasi tersebut diperhitungkan sebagai masa menjalani hukuman (Windyaningrum, 2014). Setelah menjalani proses rehabilitasi, individu akan dihadapkan pada pilihan untuk berhenti menggunakan narkoba. Maka dari itu, terdapat istilah mantan pecandu narkoba, yaitu seseorang yang telah berhenti menggunakan narkoba (Safitri, 2015).

Mantan pecandu narkoba yang sebelumnya pernah menjalani rehabilitasi dan telah berhasil berhenti menggunakan narkoba mendapatkan kesempatan untuk bisa menjadi seorang konselor adiksi. Pelibatan mantan pecandu narkoba sebagai konselor adiksi dijadikan sebagai panutan (role model) untuk memotivasi diri residen tetap fokus menjalani program rehabilitasi (Windyaningrum, 2014). Keterlibatan 
mantan pecandu sebagai konselor adiksi seperti ini telah terjadi di banyak pusat rehabilitasi narkoba di Indonesia, salah satu contohnya di Badan Narkotika Nasional Kota Jakarta Utara, Rumah Palma Therapeutic Community di Kabupaten Bandung Barat, Badan Narkotika Nasional Provinsi Jambi, dan Pusat Rehabilitasi " $X$ " Jambi. Selain sebagai konselor adiksi, di pusat rehabilitasi "X" Jambi juga memberikan kesempatan bagi mantan pecandu narkoba yang dipercaya memiliki kompetensi untuk bisa bekerja di beberapa posisi tertentu, mulai dari office boy, frontliner, hingga program manager. Jabatan ini biasanya didapatkan oleh mantan pecandu yang pernah menjalani rehabilitasi dan kemudian mengikuti pelatihan yang mendukung posisinya untuk diangkat sebagai staf/ karyawan di pusat rehabilitasi. Berdasarkan hasil wawancara yang dilakukan dengan Kepala Cabang Pusat Rehabilitasi " $X$ " Jambi terkait keterlibatan mantan pecandu yang bekerja di tempat tersebut salah satunya adalah agar mereka bisa bekerja sambil belajar, serta mendapatkan kesempatan untuk berproses menjadi lebih baik selama menjalani masa pemulihannya.

Masa pemulihan merupakan suatu masa yang akan dilewati oleh seorang pecandu yang memutuskan untuk berhenti menggunakan narkoba, baik itu atas keputusannya sendiri ataupun setelah menjalani rehabilitasi (Gunawan, dkk, 2016). Masalah bagi pelaku penyalahgunaan dan pemakai NAPZA bukan hanya sampai pada pengadilan dan berbagai tahap rehabilitasi, tetapi masalah terbesar adalah ketika mantan penyalahguna NAPZA kembali ke masyarakat. Hal itu merupakan tugas yang lebih besar bagi mereka untuk kembali menyesuaikan diri di lingkungan keluarga, teman sebaya, dan masyarakat. Mereka harus menghadapi stigma negatif dari masyarakat tentang mantan penyalahguna NAPZA dan membangun konsep diri yang jauh lebih baik dari kondisi sebelumnya (Safitri, 2015). Selain itu, menurut BNN (2006, dalam Gunawan, dkk,
2016), sebagian dari pecandu narkoba yang telah berhenti menggunakan adalah pecandu narkoba yang mengalami kambuh. Pecandu kambuhan biasanya sudah berhenti mengkonsumsi narkoba, tetapi kemudian kembali lagi menjadi pengguna narkoba. Kambuh dalam dunia adiksi disebut dengan istilah relapse yang merujuk kepada situasi ketika mantan pengguna narkoba yang sudah sempat "bersih" mulai kembali lagi menggunakan narkoba. Menurut WHO, angka kambuh dari pecandu yang pernah dirawat pada pusat-pusat terapi dan rehabilitasi adalah 60-70 persen. Hal tersebut berarti sebagian besar pecandu punya potensi dirawat dan kambuh lagi (Hanifah \& Unayah, 2011). Oleh karena itu, keberadaan mantan pecandu narkoba yang telah sembuh dan bersih dari narkoba tidak dapat begitu saja diabaikan, karena mereka memiliki potensi yang besar untuk dapat kembali ke dunia kecanduan narkoba. Bagi mereka, pemulihan (recovery) itu berlangsung selamanya (Aztri \& Milla, 2013).

Meskipun terlepas dari ketergantungan narkoba merupakan hal yang sulit untuk dijalani, namun tidak menutup kemungkinan seorang mantan pecandu dapat sembuh dari ketergantungan tersebut. Tidak sedikit yang dapat bangkit dari keterpurukan sebagai pecandu narkoba. Selain pulih dari ketergantungan narkoba, mereka pun dapat menjalani kehidupannya dengan lebih baik lagi. Salah satu sosok yang berhasil lepas dari ketergantungan narkoba adalah $\mathrm{F}$, yang merupakan mantan pecandu narkoba yang juga bekerja sebagai staf di pusat rehabilitasi " $X$ " Jambi yang telah berhasil lepas dari ketergantungan narkoba selama hampir 18 tahun dan dapat menjalani kehidupannya tanpa narkoba dan dapat berkarir di dunia rehabilitasi narkoba hingga saat ini. Dalam upaya untuk melepaskan diri dari ketergantungan terhadap narkoba dan dapat melanjutkan kehidupan dengan baik, maka dibutuhkan suatu kemampuan untuk mampu bertahan agar tidak kembali menggunakan narkoba atau relapse, terlepas dari berbagai macam 
permasalahan yang akan dihadapi oleh seorang mantan pecandu. Berkaitan dengan hal tersebut, peneliti melakukan wawancara terhadap salah seorang mantan pecandu narkoba yang bekerja di pusat rehabilitasi "X" Jambi. Berdasarkan wawancara tersebut, dapat diketahui bahwa salah satu hal yang paling penting yang dapat membuat seorang mantan pecandu tidak kembali menggunakan narkoba adalah dirinya sendiri.

Hal ini sejalan dengan penelitian yang dilakukan oleh Smestha (2015) yang menemukan bahwa salah satu faktor yang dapat mempengaruhi seorang mantan pecandu narkoba mampu bertahan untuk tidak kembali menggunakan narkoba adalah harga diri (self-esteem). Coopersmith (1967) mengemukakan bahwa harga diri (selfesteem) adalah penilaian diri yang dilakukan individu yang berkaitan dengan dirinya sendiri, yang mencerminkan sikap penerimaan dan penolakan, dan menunjukkan seberapa jauh individu tersebut percaya bahwa dirinya mampu, penting, berhasil, serta berharga.

Menurut Srisayekti, dkk (2015), harga diri (self-esteem) dipandang sebagai salah satu aspek penting dalam pembentukan kepribadian seseorang. Manakala seseorang tidak dapat menghargai dirinya sendiri, maka akan sulit baginya untuk dapat menghargai orang-orang di sekitarnya. Merriam-Webster (2016) mendefinisikan harga diri sebagai perasaan menghargai diri, kemampuan diri, serta sebuah kepercayaan dan kepuasan pada diri sendiri. Jika seseorang memiliki harga diri yang tinggi, maka ia akan menaruh nilai tinggi pada dirinya; sebaliknya, orang dengan harga diri rendah tidak percaya bahwa dirinya sangat berharga. Harga diri penting dalam kehidupan seseorang, terutama bagi seseorang yang sedang dalam masa pemulihan, seperti pemulihan adiksi. Orang yang memiliki harga diri rendah sering mengalami depresi, tidak memiliki potensi, dan toleransi pada hubungan yang kasar. Di sisi lain, orang-orang yang memiliki harga diri yang tinggi mampu belajar dari kesalahan mereka.

Berdasarkan uraian di atas, peneliti tertarik untuk mengetahui gambaran harga diri pada mantan pecandu narkoba dengan mengangkat judul penelitian "Harga Diri Mantan Pecandu Narkoba yang Bekerja Sebagai Staf Di Pusat Rehabilitasi "X" Jambi".

\section{Metode}

Penelitian ini menggunakan metode penelitian kualitatif dengan pendekatan fenomenologi. Pelaksanaan penelitian ini dilakukan pada bulan Mei 2018 di Pusat Rehabilitasi "X" Jambi. Partisipan penelitian dipilih dengan menggunakan teknik purposive sampling.

Partisipan yang dipilih sudah ditentukan karakteristiknya sesuai dengan tujuan penelitian serta bersedia untuk diwawancarai. Partisipan penelitian terdiri atas tiga orang mantan pecandu narkoba dengan rentang usia 25-45 tahun, sedang bekerja sebagai staf/ karyawan di pusat rehabilitasi " $\mathrm{X}$ " Jambi, dan telah berhenti menggunakan narkoba minimal 1 tahun.

Teknik pengumpulan data penelitian menggunakan teknik wawancara mendalam (in-depth interview). Uji keabsahan data yang digunakan adalah triangulasi, pengecekan sejawat, dan member check.

\section{Hasil dan Pembahasan}

\section{Data Profil}

Data profil memuat identitas partisipan penelitian yaitu $\mathrm{F}, \mathrm{V}$, dan $\mathrm{H}$. Adapun data profil dari ketiga partsipan penelitian ialah sebagai berikut:

\begin{tabular}{lccc}
\hline Keterangan & PF & PV & PH \\
\hline Usia & 45 tahun & 31 Tahun & 30 Tahun \\
JK & LK & LK & LK \\
Status & Belum & Menikah & $\begin{array}{c}\text { Belum } \\
\text { menikah } \\
\text { menikah }\end{array}$ \\
$\begin{array}{l}\text { Pendidikan } \\
\text { Terakhir }\end{array}$ & SMA & S1 & S1 \\
Jabatan & Program & Front & Konselor \\
& manager & Liner & Adiksi \\
Lama pulih & 15 Tahun & 2,5 & 2 Tahun \\
& & Tahun & \\
Kambuh & 2 Kali & - & - \\
\hline
\end{tabular}




\section{Keterangan Informan Tambahan}

Keterangan informan tambahan dalam penelitian ini dimaksudkan untuk menambah data pendukung mengenai partisipan yang diamati atau diketahui oleh informan yang dianggap mengenal baik partisipan dan mengetahui kondisi partisipan terkait dengan tujuan penelitian.

Informan tambahan untuk partisipan $\mathrm{F}$, $\mathrm{V}$, dan $\mathrm{H}$ adalah orang yang sama. Informan $\mathrm{S}$ merupakan kepala cabang pusat rehabilitasi "X" Jambi yang berusia 25 tahun. Selama bekerja di Pusat Rehabilitasi "X" Jambi, informan tinggal di tempat rehabilitasi tersebut bersama dengan para staf, selama beberapa bulan belakangan tinggal di rumah kosnya sendiri. Informan dianggap mengetahui kurang lebih keseharian ketiga partisipan, karena partisipan $\mathrm{F}$ dan $\mathrm{H}$ juga tinggal di rehabilitasi " $\mathrm{X}$ " Jambi. Peneliti tidak melibatkan informan lain dikarenakan keluarga dari partisipan $\mathrm{F}$ dan $\mathrm{H}$ berada di daerah lain, dan partisipan $\mathrm{V}$ mengakui lebih banyak menghabiskan waktu di tempat ia bekerja.

\section{Pembahasan}

Berdasarkan data hasil penelitian dari ketiga partisipan terlihat bahwa mantan pecandu narkoba yang bekerja sebagai staf di pusat rehabilitasi " $X$ " Jambi telah mampu mengontrol emosi, sikap, maupun perilakunya. Sebagian besar partisipan juga merasa telah menerima rasa penghargaan yang cukup dari lingkungannya. Sebagian besar partisipan tidak lagi memiliki perasaan minder dan takut ditolak dari lingkungan sekitarnya. Meskipun pada saat awal mula menjalani pemulihan, partisipan pernah merasa khawatir akan stigma sebagai seorang mantan pecandu narkoba yang bisa saja diterimanya dari lingkungan. Khusus $\mathrm{PH}$, sampai saat ini ia belum dapat sepenuhnya melupakan pengalaman pahit masa lalunya, namun hal tersebut membuat PH semakin termotivasi untuk terus melakukan perubahan yang lebih baik pada dirinya.
Di sisi lain, sebagian besar partisipan masih belum menerapkan nilai-nilai kebajikan seutuhnya, seperti menjalankan ibadah, menjauhi hal-hal yang sekiranya akan melanggar kode etik pekerjaan ataupun moral, dan masih belum menerapkan nilai-nilai yang baik pada masyarakat secara maksimal. Hanya saja, sebagian besar partisipan sudah memiliki kinerja yang cukup maksimal dalam pekerjannya, meskipun untuk $\mathrm{PF}$ dan $\mathrm{PV}$ dinilai kurang memiliki inisiatif. PF juga dinilai mengalami penurunan performa dan cenderung berada di zona nyamannya. Sebagian besar mantan pecandu narkoba yang bekerja di dunia rehabilitasi masih membutuhkan arahan secara langsung dari pimpinan dalam melakukan suatu pekerjaan, masih kurang adanya rasa inisiatif dan cenderung berada dalam zona nyaman.

Berdasarkan data yang didapat dari informan, terdapat kesesuaian hasil bahwa sebagian besar partisipan masih belum maksimal dalam melakukan pekerjaan, seperti harus diarahkan secara langsung dan kurang adanya rasa inisiatif karena terbawa pengalaman mereka di masa lalu. Selain itu, sebagian besar partisipan sudah mampu menentukan keputusan yang ada secara bijak dan melalui pertimbangan yang matang.

Berdasarkan data hasil penelitian dari ketiga partisipan terlihat bahwa faktor yang berperan dalam proses terbentuknya harga diri pada mantan pecandu narkoba yang bekerja di pusat rehabilitasi " $X$ " memiliki persamaan maupu perbedaan. Secara mendasar, faktor yang paling berperan dalam proses terbentuknya harga diri pada $\mathrm{PF}$ adalah kepemimpinan atau popularitas. PF memiliki banyak pengalaman dalam menjadi seorang pemimpin/leader di lingkungan pekerjaannya. PF juga dianggap sebagai orang yang lebih tua di lingkungan pekerjaannya, sehingga pengaruh sosok $\mathrm{PF}$ di lingkungan pekerjaannya sangat besar, tidak terkecuali saat orang-orang di sekitarnya ingin meminta pendapat maupun solusi. Hal tersebut berbeda dengan PV 
yang mana faktor yang paling berperan dalam proses terbentuknya harga diri adalah penerimaan diri dan keluarga. PV tidak lagi merasa minder dengan statusnya sebagai mantan pecandu narkoba bahkan merasa bangga dengan statusnya tersebut, karena menurutnya ia mampu menginspirasi orang lain untuk dapat berubah menjadi orang yang lebih baik. Saat ini, PV telah sering diberikan kepercayaan ataupun amanah oleh keluarganya.

Begitu pula $\mathrm{PH}$, yang telah memiliki hubungan yang baik dengan orangtuanya, meskipun dari awal berhenti menggunakan narkoba hingga saat ini, ia belum berkesempatan untuk bertemu orangtua maupun keluarganya. Selanjutnya, faktor yang paling berperan dalam proses terbentuknya harga diri pada $\mathrm{PH}$ adalah penerimaan diri dan kebutuhan akan penghargaan. Maka dari itu, dapat dilihat bahwa berdasarkan keempat faktor dari teori yang peneliti gunakan, masing-masing berperan dalam proses terbentuknya harga diri pada mantan pecandu narkoba. Seluruh partisipan memiliki pengaruh yang cukup besar di lingkungan pekerjaannya saat ini dengan jabatan dan peran yang mereka berikan di pusat rehabilitasi tersebut.

Selain itu, dari hasil penelitian yang dilakukan sebagian besar partisipan mengakui bahwa mereka sangat membutuhkan pengakuan dari orang lain terkait perubahan positif yang mereka dapatkan setelah pulih dari ketergantungan terhadap narkoba. Pulih dari ketergantungan terhadap narkoba merupakan kebanggaan tersendiri bagi seluruh partisipan.

Berdasarkan penelitian yang telah dilakukan pada partisipan $\mathrm{F}, \mathrm{V}$, dan $\mathrm{H}$ menghasilkan temuan yang belum didapatkan dari penelitian terkait sebelumnya dan begitu pula dari teori yang peneliti gunakan. Peneliti menemukan hasil bahwa terdapat faktor lain yang juga berperan dalam proses terbentuknya harga diri pada mantan pecandu narkoba, yaitu kebutuhan akan pengakuan dari orang lain yang termasuk ke dalam kebutuhan akan penghargaan. Kebutuhan akan penghargaan sendiri terdapat dalam teori hierarki Abraham Maslow mengenai kebutuhankebutuhan dasar pada diri seseorang.

\section{Kesimpulan}

Berdasarkan penelitian yang telah dilakukan, diperoleh kesimpulan dimana harga diri pada ketiga partisipan cenderung mengarah ke dalam kategori harga diri sedang berdasarkan macam-macam harga diri yang dikemukakan di dalam teori harga diri oleh Coopersmith. Kesimpulan lainnya yang didapatkan dalam penelitian ini adalah sebagai berikut:

a. Terkait harga diri pada mantan pecandu narkoba yang bekerja di pusat rehabilitasi " $X$ " Jambi secara keseluruhan dapat disimpulkan bahwa ketiga partisipan telah mampu mengontrol emosi, sikap, maupun perilakunya. Sebagian besar partisipan juga merasa telah menerima rasa penghargaan yang cukup dari lingkungannya, seperti keluarga dan lingkungan pekerjaannya. Di sisi lain, sebagian besar partisipan masih belum menerapkan nilai-nilai kebajikan seutuhnya, seperti menjalankan ibadah, menjauhi hal-hal yang sekiranya akan melanggar kode etik pekerjaan ataupun moral, dan masih belum menerapkan nilai-nilai yang baik pada masyarakat secara maksimal. Sebagian besar partisipan sudah memiliki kinerja yang cukup maksimal dalam pekerjaannya, meskipun mereka sering membutuhkan arahan secara langsung dari atasan dan cenderung kurang memiliki inisiatif.

b. Terkait faktor yang beperan dalam proses terbentuknya harga diri pada mantan pecandu narkoba yang bekerja di pusat rehabilitasi " $\mathrm{X}$ " Jambi secara keseluruhan dapat disimpulkan bahwa ketiga partisipan telah dapat menerima keadaan dirinya, termasuk kenyataan bahwa dahulu mereka adalah seorang mantan pecandu narkoba dan telah banyak merugikan orang-orang di sekelilingnya. Seluruh partisipan memiliki pengaruh yang cukup besar di 
lingkungan pekerjaannya saat ini dengan jabatan dan peran yang mereka berikan di pusat rehabilitasi tersebut. Seluruh partisipan telah memiliki hubungan yang baik dengan orangtua maupun keluarga mereka. Sebagian besar partisipan tidak lagi memiliki perasaan minder dan takut ditolak dari lingkungan sekitarnya. Meskipun pada saat awal mula menjalani pemulihan, sebagian besar partisipan pernah merasa khawatir akan stigma yang bisa saja diterimanya sebagai seorang mantan pecandu narkoba.

c. Faktor lain yang juga berperan dalam proses terbentuknya harga diri partisipan sebagai mantan pecandu narkoba adalah kebutuhan akan penghargaan.

\section{Saran}

Diharapkan instansi terkait dapat lebih memberikan respon yang positif dan mengupayakan suatu solusi dalam bentuk pertemuan ataupun kegiatan yang lebih bermanfaat bersama seluruh staf di pusat rehabilitasi "X" Jambi agar para staf yang berstatus sebagai mantan pecandu narkoba. Mantan pecandu narkoba yang bekerja di pusat rehabilitasi " $X$ " Jambi yang masih belum memenuhi beberapa nilai-nilai kebajikan, seperti menjalankan ibadah sesuai dengan agama/kepercayaan masing-masing serta menjaga etika dan moral harus mulai menerapkannya dalam kehidupan seharihari. Untuk penelitian selanjutnya diharapkan dapat mengacu kepada ruang lingkup yang lebih luas, seperti penelitian mengenai harga diri pada mantan pecandu narkoba yang bekerja di rehabilitasi lainnya atau mantan pecandu narkoba yang berada di kota Jambi dengan batasan masalah yang berbeda agar mendapatkan gambaran yang lebih luas.

\section{Daftar Pustaka}

Aztri, Sherly \& Milla, Mirra, N. (2013). Rasa berharga dan pelajaran hidup mencegah kekambuhan kembali pada pecandu narkoba studi kualitatif fenomenologis. Jurnal Psikologi, 9 (1)
Badan Narkotika Nasional. Hasil survei penyalahgunaan dan peredaran gelap narkoba pada kelompok pelajar dan mahasiswa sdi 18 Provinsi Tahun 2016. Ringkasan Eksekutif Hasil Survei BNN. BNN dan PPK Universitas Indonesia, 2016

Badan Narkotika Nasional. Survei prevalensi penyalahgunaan narkoba pada kelompok rumah tangga di 20 Provinsi Tahun 2015. Pusat Penelitian Data dan Informasi, 2016

Badan Narkotika Provinsi DKI Jakarta, Modul pencegahan penyalahgunaan narkoba, disusun oleh Tim Bagian prevensi BNP DKI, 2009 Jauhinarkoba. com/pemicuterjadinya-penyaIahgunaan-narkotika

Coopersmith, Stanley. (1967). The antecendents of self-esteem. San Francisco: Freeman

Gunawan, K.W., Priyatama, A.N., Setyanto, A.T. (2016). Pengaruh pelatihan pemafaan terhadap peningkatan self-esteem pecandu narkoba di program re-entry balai besar rehabilitasi Badan Narkotika Nasional (BNN) Lido, Bogor. Jurnal Wacana Psikologi, 8 (16)

Hanifah, Abu \& Unayah, Nunung. (2011). Mencegah dan menanggulangi penyalahgunaan NAPZA melalui peran serta masyarakat. Informasi, 16 (1)

Kementerian Kesehatan Republik Indonesia. (2014). Gambaran umum penyalahgunaan narkoba di Indonesia. Buletin Jendela Data dan Informasi Kesehatan

Martini, Aisyah, S., Gustamy, R., Widhiastuti, S.K., Prabandari, W. (2015). Pembinaan UKS kesehatan jiwa (NAPZA: Narkotika, Psikotropika, dan Zat Adiktif), gangguan belajar. Modul Field Lab Semester V, Edisi Revisi III. Fakultas 
Kedokteran, Universitas Sebelas

Maret

Safitri, Lila, D. (2015). Resiliensi pada mantan penyalahguna NAPZA. Artikel eJournal. Jurnal Bimbingan dan Konseling, Edisi ke-4 Tahun ke-4

Smestha, Bias, R. (2015). Pengaruh selfesteem dan dukungan sosial terhadap resiliensi mantan pecandu narkoba. Fakultas Psikologi, Universitas Syarif Hidayatullah Jakarta

Srisayekti, Wilis., Setiady, David, A., Sanitioso, Rasyid, Bo. (2015). Harga diri (self-esteem) terancam dan perilaku menghindar. Jurnal Psikologi, 42 (2), 141-156

Windyaningrum, Rachmawati. (2014). Komunikasi terapeutik konselor adiksi pada korban penyalahgunaan narkoba di Rumah Palma Therapeutic Community Kabupaten Bandung Barat. Jurnal Kajian Komunikasi, 2 (2) 